Portland State University

PDXScholar

Environmental Science and Management

Faculty Publications and Presentations

Environmental Science and Management

$4-2009$

\title{
Mangrove-Exported Nutrient Incorporation by Sessile Coral Reef Invertebrates
}

\author{
Elise F. Granek \\ Portland State University, graneke@pdx.edu \\ Jana E. Compton \\ US Environmental Protection Agency \\ Donald L. Phillips \\ US Environmental Protection Agency
}

Follow this and additional works at: https://pdxscholar.library.pdx.edu/esm_fac

Part of the Environmental Sciences Commons, Plant Sciences Commons, and the Zoology Commons Let us know how access to this document benefits you.

Citation Details

Granek, E. F., Compton, J. E., \& Phillips, D. L. (2009). Mangrove-Exported Nutrient Incorporation by Sessile Coral Reef Invertebrates. Ecosystems, 12(3), 462-472.

This Article is brought to you for free and open access. It has been accepted for inclusion in Environmental Science and Management Faculty Publications and Presentations by an authorized administrator of PDXScholar. Please contact us if we can make this document more accessible: pdxscholar@pdx.edu. 


\title{
Mangrove-Exported Nutrient Incorporation by Sessile Coral Reef Invertebrates
}

\author{
Elise F. Granek, ${ }^{1,2 *}$ Jana E. Compton, ${ }^{3}$ and Donald L. Phillips ${ }^{3}$
}

\begin{abstract}
${ }^{1}$ Department of Zoology, Oregon State University, Corvallis, Oregon 97331, USA; ${ }^{2}$ Environmental Sciences and Management, Portland State University, P.O. Box 751, Portland, Oregon 97207, USA; ${ }^{3}$ Western Ecology Division, US Environmental Protection Agency, National Health and Environmental Effects Research Laboratory, Corvallis, Oregon 97333, USA
\end{abstract}

\begin{abstract}
Coastal mangrove forests were historically considered as a source of organic matter (OM) for adjacent marine systems due to high net primary production; yet recent research suggesting little uptake through the food web because of low nutritional quality, challenges the concept of trophic linkage between mangrove forests and coral reefs. To examine the importance of mangrove forests to coral reef nutrient availability, we examined sessile reef-forming invertebrate consumers including hard corals, sponges, a bivalve mollusc, polychaete annelid and tunicate, and potential sources of OM (decaying mangrove leaves, microalgae, macroalgae, and seagrass) in Bocas del Toro, Panama. Using stable isotope analyses of $\delta^{34} \mathrm{~S}$ and $\delta^{13} \mathrm{C}$ and a concentrationdependent version of the IsoSource mixing model, we were able to discriminate among and determine the range of potential contributions of our four OM sources to consumers. Contributions of microalgae and macroalgae were often indeterminate due to high variability, yet seagrass and mangrove
\end{abstract}

Received 4 August 2008; accepted 19 January 2009;

published online 18 February 2009

Electronic supplementary material: The online version of this article (doi:10.1007/s10021-009-9235-7) contains supplementary material, which is available to authorized users.

Author Contributions: EFG conceived of study, performed all field research, conducted data analysis and wrote the first draft of the manuscript. JEC assisted with study design, methods for sample processing, data analysis, and writing of the manuscript. DLP contributed new isotope models, assisted with data analysis, and contributed to writing of the manuscript.

*Corresponding author; e-mail: graneke@pdx.edu contributions were often substantial. Mangrove OM ranged across sites and species of filter feeders from 0 to $57 \%, 7$ to $41 \%$, and 18 to $52 \%$ for sponges, file clams, and feather duster worms, respectively. Mangrove contribution to corals (Acropora cervicornis, Agaricia fragilis, Agaricia tenuifolia, Montastrea annularis, Diploria sp.) ranged from 0 to $44 \%$. To examine whether OM contribution varied with distance from mangroves, we conducted a sponge transplant experiment that demonstrated declining mangrove contribution across three sponge species with increasing distance from the shore. These results supported the hypothesis of mangrove-coral reef nutrient linkages, providing the first evidence that mangrove inputs of $\mathrm{OM}$ to sessile invertebrates are substantial, accounting for $0-57 \%$ of the composition.

Key words: bivalve; coral; macroalgae; mangrove forest; nutrient exchange; phytoplankton; seagrass; sponge; stable isotope.

\section{INTRODUCTION}

Mangrove forests are productive tropical and subtropical coastal marine ecosystems (Odum and Heald 1975; Jennerjahn and Ittekkot 2002) that have net primary production (NPP) in considerable excess of the carbon utilized in the system, with an estimated $20-30 \%$ of NPP exported (Duarte and Cebrian 1996; Bouillon and others 2008). Odum 
and Heald (1972, 1975) suggested that the high productivity from mangrove trees is incorporated into food webs in and adjacent to mangroves due to outwelling of mangrove-derived nutrients. However, more recent studies have indicated that other primary producers (phytoplankton, micro- and macroalgae) are more important because of their higher nutritional quality and digestibility compared to mangrove matter (for example, Ambler and others 1994; Newell and others 1995; Loneragan and others 1997; France 1998).

The moderate to high export of NPP has led various researchers to examine the contributions of mangrove-fixed carbon to adjacent inshore habitats (for example, seagrass beds) and open ocean (for example, Duarte and Cebrian 1996; Sheaves and Molony 2000; Jennerjahn and Ittekkot 2002) including a suite of studies on the incorporation of mangrove production into organisms ranging from zooplankton (Bouillon and others 2000) to mobile marine invertebrates (for example, France 1998; Fry and Smith 2002; Werry and Lee 2005) and fishes (for example, Sheaves and Molony 2000; Nagelkerken and van der Velde 2004a, b; Benstead and others 2006). These mobile organisms may serve as a pathway for the export of mangrovederived nutrients. However, the question of mangrove nutrient incorporation into structure-forming coral reef organisms remains unresolved. Because corals and sponges are sessile, they may serve as good integrators of net flux or supply of mangrove-derived materials to associated reefs where they provide essential habitat and food resources in reef systems and form the dominant structure and 'cement' on many tropical reefs (Suchanek and others 1983; Connell and others 1997; Wulff 1997, 2000).

In this study we examine the hypothesis of trophic linkages between mangrove forests and sessile coral reef species, including corals, sponges, file clams, and feather duster worms. We also investigate whether distance from and absence of mangroves adjacent to study reefs affect the level of incorporation by: (1) conducting a sponge transplant experiment and (2) sampling natural populations on reefs at varying distances from mangrove forests and adjacent to cleared mangrove areas. We employ stable isotope analyses to provide insights into the relative importance of the various primary producers contributing to a system (Bouillon and others 2002), as the relative abundance of the food sources are reflected in the stable isotope ratios (for example, ${ }^{13} \mathrm{C}$ vs. ${ }^{12} \mathrm{C}$ ) of consumer tissues. We sought to determine whether exported mangrove $\mathrm{OM}$ is, indeed, contributing to reef structure and community composition such that loss of mangrove habitat may affect nutrient availability on inshore and offshore reef systems.

\section{MethodS}

\section{Study Area}

This study included samples from six sites around Bocas del Toro Province, Panama (Figure 1) including five sites in Almirante Bay within $20 \mathrm{~km}$ of each other, and one reference site outside of Almirante Bay located approximately $30 \mathrm{~km}$ from the bay sites. Three bay sites were on Isla Colon, one was on Isla Pastores, and one was on the mainland south of Almirante (Figure 1). All sites meeting the following criteria were selected: (1) at least $100 \mathrm{~m}$ long stretches of cleared Rhizophora mangle red mangroves adjacent to at least $100 \mathrm{~m}$ long stretches of intact fringing red mangroves; (2) fringing or patch reefs occurred within $100 \mathrm{~m}$ of the seaward mangrove edge; (3) more than $2 \mathrm{~km}$ from major human development to exclude major sources of anthropogenic nutrients; and (4) located within $20 \mathrm{~km}$ of the research station. At all sites, primary producers and sessile reef invertebrates were sampled along a gradient from the mangrove forest to the reef slope.

At each site, 16 semi-permanent, 20-m long transects were established, across four habitat types and two levels of mangrove condition; there were two replicate transects in each habitat type $\times$ mangrove condition combination. Mangrove condition was either intact or cleared, and the habitat types included mangrove center $(\mathrm{MC})$ within the mangrove forest, mangrove edge (ME) at the seaward edge of the mangroves, reef flat (RF) on the inshore patch reef, and reef slope (RS) on the sloping reef. MC and ME transects were approximately $15 \mathrm{~m}$ apart, $\mathrm{ME}$ to RF transects approximately $50 \mathrm{~m}$ apart, and RF to RS transects approximately $250 \mathrm{~m}$ apart. Intact and cleared areas were separated by more than $100 \mathrm{~m}$.

Sites along Isla Colon included, from NW to SE, Red Point (RP), Punta Caracole North (PCN), and Punta Caracole South (PCS). The site on Isla Pastores is referred to as Pastores and the mainland site close to Punta Gallinazo as Gallinazo. The coastline at all Almirante Bay sites was characterized by Rhizophora mangle trees, except where stands had been removed for subsistence agriculture, house construction, or view sheds (to create an ocean view). Below we refer to these as "cleared" areas, and contrast them to "intact" areas with undisturbed mangroves. Cleared areas ranged from 100 to $300 \mathrm{~m}$ in length along the 


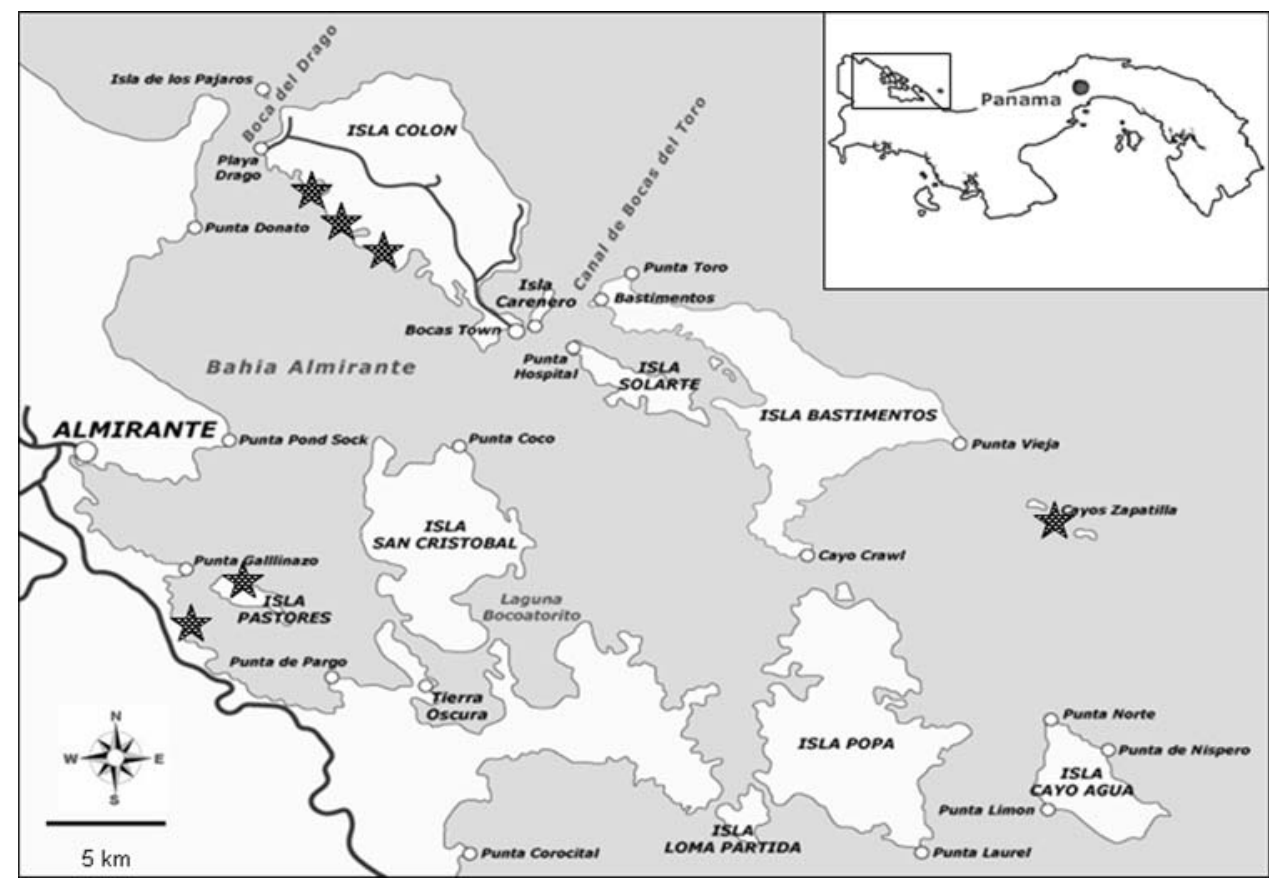

Figure 1. Map of study area in Bocas del Toro, Panama in the Caribbean Sea. Three sites were located on Isla Colon: Red Point, Punta Caracole North (PCN) and Punta Caracole South (PCS). One site was located on Isla Pastores (Pastores) and one site located on the mainland at Punta Gallinazo (Gallinazo). The reference site was located outside of Almirante Bay on Zapatillas Caye (Zapatillas).

shore. On Isla Colon, clearance occurred approximately 8 years prior to this study and cleared areas were characterized by submerged decaying prop roots on the substrate with substantial cover of macroalgae inshore and of the seagrass Thalassia testudinum further from shore. Little three-dimensional structure remained in these cleared areas. At the Pastores and Gallinazo sites, clearance occurred approximately 12 months prior to sampling and disturbed areas retained dead, exposed mangrove stands covered subtidally with algae, and fringed by seagrass along the seaward edge. At Pastores and Gallinazo, subtidal root structure in cleared areas was substantially greater, leading to subtidal structure intermediate between intact areas and the three Isla Colon cleared areas. Intact areas were characterized by submerged prop roots colonized by oysters, sponges, sporadic coral heads, and infrequently epibiotic algae with occasional nonforested channels between trees. At all five sites, reef flats were predominantly Porites furcata and Millepora alcicornis interspersed with macroalgae. Reef slopes were a mix of hard corals, soft corals, and numerous sponge colonies; turbidity was often high and visibility was generally low on reef slope transects. Sites located in the bay experienced daily flushing when the tide would enter predominantly through the northern mouth of the bay and be flushed through the southern mouth (Figure 1).

A reference site (no mangroves present for $>10 \mathrm{~km}$ ) was located at Zapatillas Caye (Figure 1) outside of Almirante Bay. This open ocean site is characterized by strong wave action, lower turbidity, high visibility (implying lower nutrients) and flushing, and different sessile community composition, dominated by hard corals with few sponge colonies and extremely low macroalgal cover. This Caye was selected because mangroves were never present near the site.

\section{Sample Collection and Preparation}

\section{Naturally Occurring Organisms}

In March and July 2004, primary producer (representing 4 categories of potential organic matter $[\mathrm{OM}]$ sources) and sessile reef invertebrate samples were collected from the six Bocas del Toro sites. Four individuals were collected per species per transect. Primary producers included decaying Rhizophora mangle mangrove leaves (Fry and Smith 2002), collected from the substrate under mangrove trees and rinsed of detritus, Thalassia testudinum seagrass blades, dominant macroalgae (Padina spp., Caulerpa spp., Dictyota spp., Halimeda spp., and composite filamentous and branching red algae), and phytoplankton. Phytoplankton was sampled by filtering 2-l samples of seawater collected over the reef slope onto a $25-\mathrm{mm} \times 0.7 \mu \mathrm{m}$ Whatman $\mathrm{GF} / \mathrm{F}$ glass microfiber filter. Sessile reef invertebrates included corals (Agaricia tenuifolia, A. fragilis, Acropora cervicornis, Porites furcata, and Montastrea sp.), sponges (Amphimedon compressa, Aplysina fulva, 
Niphates erecta), the rough file clam (Lima scabra), solitary tunicate (Phallusia nigra), and the magnificent feather duster worm (Sabellastarte sp.; found in sufficient abundance at only one site).

Coral samples were prepared by airbrushing tissue off the coral skeleton to collect live tissue. File clams were removed from their shells and all tissue was retained for analysis. Feather duster worms were separated from their tubes, and tissue and tubes were analyzed separately. Samples were rinsed in deionized (DI) water and dried at $60^{\circ} \mathrm{C}$ until no further weight loss occurred. All primary producer and filter feeder samples were ground for 2 min using a SPEX ball mill to grind and homogenize whole body tissue, redried at $60^{\circ} \mathrm{C}$ for at least $4 \mathrm{~h}$, then weighed into tin cups for analysis with an Elemental Analyzer. Samples were analyzed for $\delta^{13} \mathrm{C}$ on a Costech ECS 4010 elemental analyzer interfaced through a Thermo-Finnigan Conflo III to a Thermo-Finnigan Delta Plus XP isotope ratio mass spectrometer at the EPA Integrated Stable Isotope Research Facility in Corvallis, Oregon. Samples were analyzed for $\delta^{34} S$ at the Colorado Plateau Stable Isotope Laboratory at Northern Arizona University on a Carlo Erba NC2100 Elemental Analyzer interfaced to a Thermo-Finnigan Delta Plus Advantage isotope ratio mass spectrometer. To combust high-weight samples with low \% sulfur, a Costech Analytical Technologies ECS4010 Elemental Analyzer with a 20-ml $\mathrm{O}_{2}$ loop was used in place of the CE NC2100.

Isotope values are expressed as $\delta^{34} \mathrm{~S}$ or $\delta^{13} \mathrm{C}$ (with units of $\%$ ) determined by the following equation: $\delta^{34} \operatorname{Sor}^{13} \mathrm{C}=\left[\left(R_{\text {sample }} / R_{\text {standard }}\right)-1\right] \times 1000$, where $R={ }^{13} \mathrm{C} /{ }^{12} \mathrm{C},{ }^{34} \mathrm{~S} /{ }^{32} \mathrm{~S}$. Reference standards are PeeDee Belemnite Carbonate and Canyon Diablo Troilite for $\delta^{13} \mathrm{C}$ and $\delta^{34} \mathrm{~S}$, respectively. Internal standards were interspersed with samples in all runs to control for drift within and among runs.

\section{Zooxanthellae}

To examine differences in isotopic values between coral tissue (the animal host) and zooxanthellae (the algal symbiont, a dinoflagellate), we extracted zooxanthellae from the host coral tissue of five frozen Fungia scutaria specimens available at Oregon State University. We then examined the $\delta^{34} S$ signature of the algal zooxanthellae to determine whether microalgae (in this case dinoflagellates) that are confined inside a coral host have a similar sulfur isotopic ratio to phytoplankton in the water column. We separated coral tissue from the skeleton with an airbrush attached to a SCUBA tank then centrifuged the wet tissue samples to separate zooxanthellae from the animal host tissue per Weis and others (2001). All samples were dried then processed for $\delta^{34} \mathrm{~S}$ using the above protocol. $\delta^{13} \mathrm{C}$ values from the literature were utilized (Muscatine and others 1989).

\section{Sponge Transplant Experiment}

We conducted a transplant experiment to investigate whether distance from mangroves affects mangrove-derived nutrient incorporation levels. In March 2004, large colonies of three sponge species (A. fulva, A. compressa, N. erecta) were identified: $N$. erecta source colony along the mangrove edge, $A$. fulva colony on a reef flat, and $A$. compressa colony on a reef slope. A segment of each sponge colony was removed and cut into $1003-\mathrm{cm}$-long pieces in length. Each sponge piece was measured for volume and attached with a zip-tie to a $1.27-\mathrm{cm}$ diameter $\times 7.62-\mathrm{cm}$ long PVC tube. All sponge segments were strung on a line at the collection site to acclimate to the PVC for $24-48 \mathrm{~h}$, following which the sponge pieces were randomly outtransplanted to the 16 transects at the Punta Caracole North site on Isla Colon (see Figure 1). Six replicates of each species were attached to rebar stakes along each transect in each habitat type including: (1) center of the mangroves (MC), (2) along the seaward edge of the mangroves (ME), (3) on the reef flat (RF) approximately $50 \mathrm{~m}$ from the mangrove edge, and (4) along the reef slope (RS) approximately $250 \mathrm{~m}$ from the mangrove edge. Sponge transplants were left in the field for approximately 90 days to allow for tissue turnover to occur. At about 75 days, an unidentified predator began biting the sponge fragments, so length and volume results are not presented. Sponges were rinsed with DI water, dried at $60^{\circ} \mathrm{C}$ until no further weight loss occurred, and prepared for isotope analysis as indicated above.

\section{Data Analysis Techniques}

For each of the invertebrates we used mixing models to determine the proportional contribution of the four OM sources: mangrove detrital leaves, seagrass, macroalgae, and microalgae (phytoplankton and zooxanthellae). We used the $\delta^{13} \mathrm{C}$ and $\delta^{34} \mathrm{~S}$ values of mangrove detrital leaves (rather than green leaves) because this senesced stage is the form in which leaves are supplied to marine food webs. For the $N$. erecta samples from the transplant experiment, a fifth source, mangrove wood, was added based on data from Fry and Smith (2002). Mangrove wood was used as a proxy for mangrove prop roots on which $N$. 
erecta grows naturally and from which $N$. erecta may extract or exchange nutrients (Ellison and others 1996). Results represent an average of the four individuals of each primary producer and each consumer analyzed per transect.

Trophic fractionation factors for $\mathrm{C}$ and $\mathrm{S}$ (change in $\delta^{13} \mathrm{C}$ and $\delta^{34} \mathrm{~S}$ moving from a lower to higher trophic position) were assigned as $0.5 \%$ (for example, France and Peters 1997; Vander Zanden and Rasmussen 2001; McCutchan and others 2003). $\delta^{15} \mathrm{~N}$ measurements were not used in this study due to the difficulty of predicting trophic position and therefore fractionation factors for $\mathrm{N}$, which has a much higher fractionation per trophic level than C or S (McCutchan and others 2003).

With four or five sources and only two isotopic tracers, there is no unique combination of sources observable in invertebrate isotopic signatures. For these situations, the mixing model software IsoSource (Phillips and Gregg 2003) can calculate the range of source contributions consistent with isotopic mass balance based on the four OM sources. However, standard multi-tracer mixing models (such as the one used in IsoSource) assume that for each food source, its proportional contribution to the consumer of one tracer element (for example, C) is the same as its contribution of another tracer element (for example, S). When there are substantial differences in elemental concentrations among different sources, this assumption may not be appropriate. Phillips and Koch (2002) outlined a concentration-dependent mixing model that incorporates concentration data as well as isotopic composition in determining source proportions. We wrote a computer program in SAS that reproduces the algorithms in IsoSource to find all possible combinations of sources that are consistent with the observed consumer isotopic composition, but using this concentration-dependent mixing model instead of the standard mixing model. The concentration-dependent model gives separate results for source contributions to consumer C, S, and overall biomass; and we focused our results and discussion on the latter part.

The Increment parameter as defined in IsoSource (the smallest recognized difference among proportions) was set at $1 \%$. The Tolerance parameter reflects how close the predicted consumer isotopic composition for a given set of source proportions must be, compared to the observed composition, for that set of proportions to be considered feasible (Phillips and Gregg 2003). As such, it can reflect the degree of uncertainty or variability in various input variables. We found that the median SE for OM source signatures was $0.3 \%$, the median SE for consumer signatures was $0.2 \%$, and the SE's for C and $\mathrm{S}$ trophic fractionation were 0.1 and $0.5 \%$, respectively (McCutchan and others 2003). To reflect these uncertainties, we set the Tolerance parameter at the largest of these values, $0.5 \%$, and increased it to $1.0 \%$ when no solutions were found at the lower Tolerance value. In the results of the mixing model, small ranges of percent contribution indicate well-constrained (more precise) estimates of the source contribution, assuming that all food sources have been included in the model.

\section{RESUltS}

Using $\delta^{13} \mathrm{C}$ and $\delta^{34} \mathrm{~S}$, we were able to clearly discriminate among the four OM sources because the $\delta^{13} \mathrm{C}$ values of mangrove, microalgae, macroalgae, and seagrass were each separated by at least $4.5 \%$ and the $\delta^{34} S$ values of mangroves separated from the other sources by $7 \%$ o (see sponge experiment results; Figure 2). The polygon formed by the OM sources roughly outlines the range of consumer values explained by the sources considered, although the concentration-dependent model may make the edges somewhat curved rather than straight (Phillips and Koch 2002). Mangrove Edge values that lie outside the polygon likely reflect incorporation of particulates from mangrove woody matter that has a lower $\delta^{34} \mathrm{~S}$ value of approximately $4.8 \%$ (and $\delta^{13} \mathrm{C}$ value of $-27.5 \%$; Fry and Smith 2002). The OM sources reflected consistent $\delta^{34} \mathrm{~S}$ and $\delta^{13} \mathrm{C}$ values across sites to within $1.5 \%$. If mangrove woody matter values (Fry and Smith 2002) are added as an additional source, all consumers fall within the new polygon formed.

\section{Naturally Occurring Filter Feeders}

Filter feeding invertebrates including the rough file clam (L. scabra), feather duster worm (Sabellastarte sp.), and three sponge species (A. compressa, A. fulva, $N$. erecta) reflected signatures of mangrove-derived nutrients along most transects (Figure 3 and Supplementary Table 1). Rough file clams exhibited intermediate levels of contribution from mangroves ranging from 7 to $41 \%$ across sites. Feather duster worms reflect a substantial contribution of mangrove-derived nutrients both in tissue and tube composition, ranging from 18 to $52 \%$ for live tissue and from 30 to $49 \%$ for tubes across transects. Isotopic values of organisms sampled adjacent to cleared mangrove areas did not differ from those sampled adjacent to the intact mangrove areas.

The sponge species reflected variable mangrove contributions based on the species, site, and dis- 

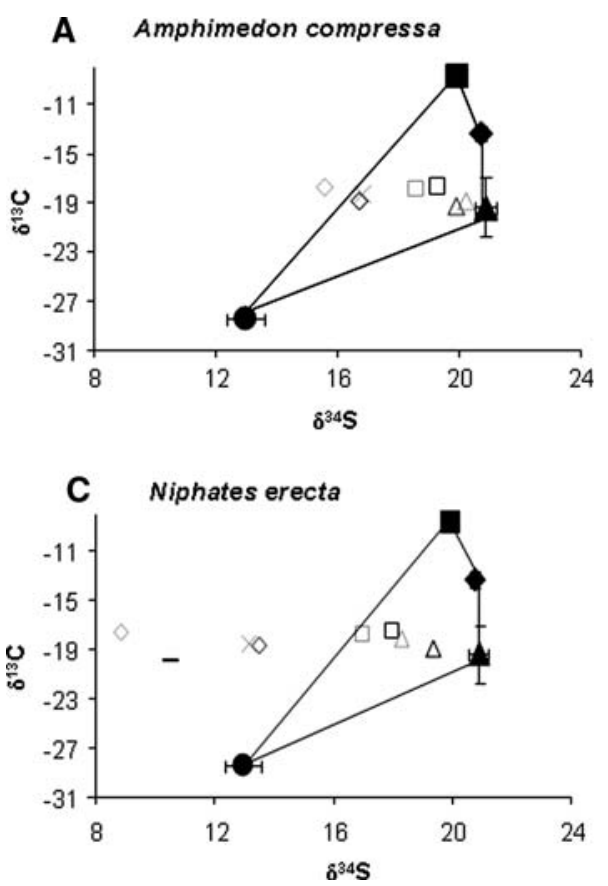
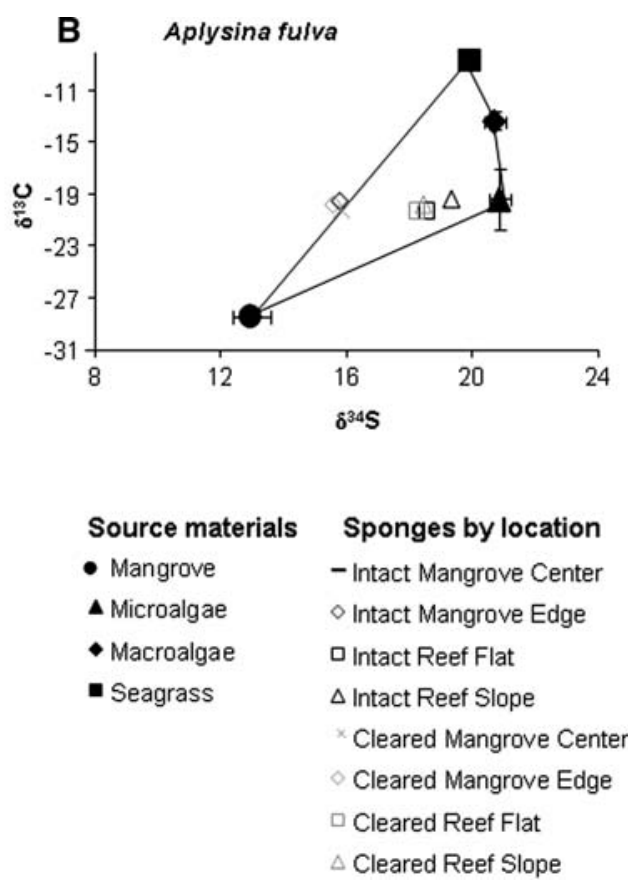

Figure 2. $\delta^{34} \mathrm{~S}$ and $\delta^{13} \mathrm{C}$ ratios for primary producer sources (macroalgae, microalgae, mangrove, and seagrass) and three species of tropical reef sponges at sites along the intact and cleared transects. The mixing space of the primary producer sources is roughly defined by the polygon, although the concentration-dependent model may make the edges somewhat curved rather than straight (Phillips and Koch 2002). The error bars represent the range of $\delta^{34} \mathrm{~S}$ and $\delta^{13} \mathrm{C}$ signatures across samples for a given taxon; some error bars are smaller than the symbols. tance from mangroves (Supplementary Table 1). At all sites, A. compressa and $A$. fulva isotopic values indicated a mangrove contribution, whereas $N$. erecta samples were inconclusive along some transects (the \% contribution spanned 0 , indicating that mangroves may or may not be a source). Mangrove contribution across site $\times$ transect combinations ranged from 3 to $48 \%$ for $A$. compressa; 14 to $57 \%$ for $A$. fulva; and 0 to $52 \%$ for $N$. erecta. The tunicate $P$. nigra, on the other hand, reflected little incorporation of mangrove-derived nutrients with $0-16 \%$ contribution at two sites and $0 \%$ contribution at a third site (Figure 3, Supplementary Table 1).

\section{Corals}

The coral species reflected variable mangrove contribution based on species, site and distance from mangroves (Figure 4, Supplementary Table 2). Mangrove contribution to $A$. fragilis was variable ranging from 0 to $30 \%$ across reef sites whereas $A$. fragilis colonies growing directly on mangrove prop roots reflected higher mangrove contribution (20$40 \%$ ). Similarly, mangrove contribution to A. tenuifolia ranged from 0 to $30 \%$ on reef transects, but 20 to $40 \%$ when attached to mangrove prop roots. Mangrove contribution to A. cervicornis and Diploria sp. was conclusive, ranging from 4 to $33 \%$ and 4 to $44 \%$, respectively. M. annularis, a more heterotrophic coral, reflected a mangrove contribution of $0-$ $33 \%$ with two sites indicating a clear contribution.

\section{Zooxanthellae}

Zooxanthellae $\delta^{13} \mathrm{C}$ signatures from the literature (Muscatine and others 1989) are consistent with those of phytoplankton measured from water samples in this study (Figure 2). Similarly, our $\delta^{34} \mathrm{~S}$ values from centrifuged zooxanthellae (20.2$22.0 \%$ ) fell within the range of $\delta^{34} \mathrm{~S}$ values for phytoplankton sampled in this study. Based on these findings, we group zooxanthellae with phytoplankton into a microalgae category for all analyses (Supplementary Tables 1 and 2).

\section{Sponge Transplant Experiment}

All transplanted sponges incorporated mangrovederived matter, but the amount depended upon the proximity of the transplants to mangroves. All sponge species responded similarly, with individuals transplanted into the Mangrove Center or Mangrove Edge areas demonstrating higher levels of mangrove contribution, and transplants to the Reef Flat and Reef Slope exhibiting intermediate and low mangrove contribution, respectively (Figure 5). Transplants to intact mangroves were similar in mangrove contribution to transplants in cleared mangrove areas (for example, in intact versus cleared Mangrove Edge transects, A. compressa transplants: $44 \%$ vs. $42 \%$ contribution). Based on the four OM sources, the results for $N$. erecta were inconclusive; however, when mangrove wood was added to the model (Fry and Smith 

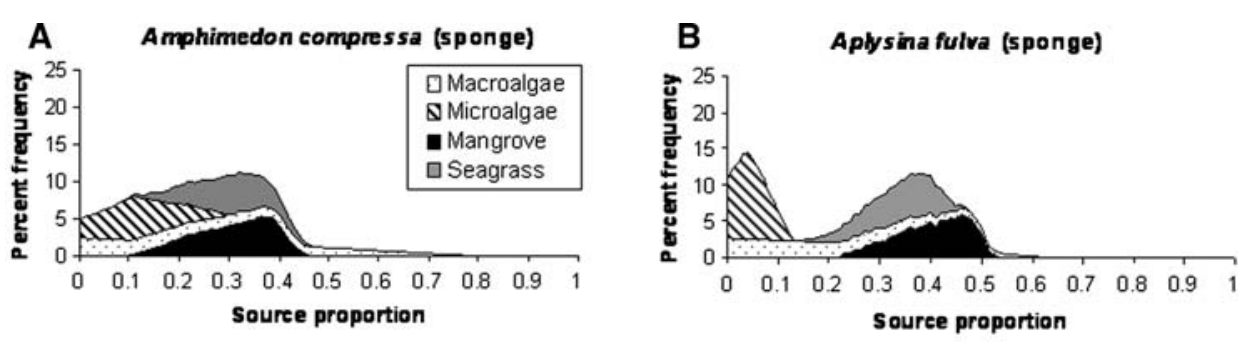

Figure 3. The range of potential biomass contributions of each organic matter source (macroalgae, microalgae, mangroves, seagrass) for filter feeders and coral using the concentrationdependent mixing model.
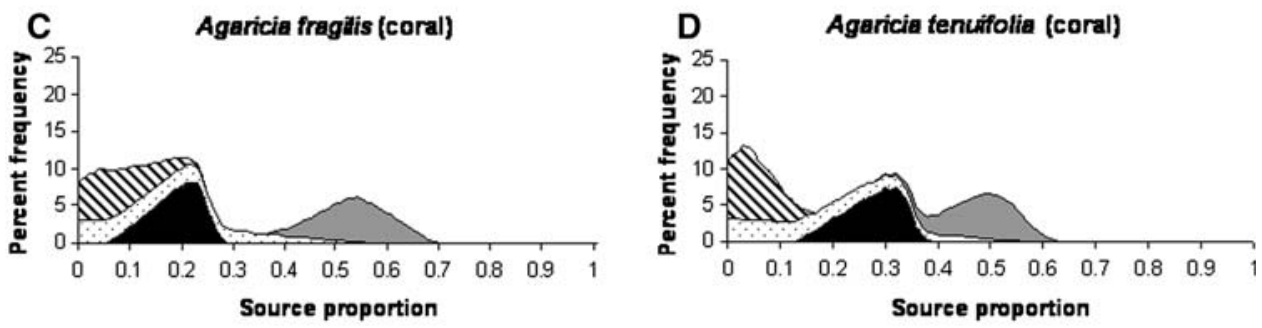

The $x$-axis is the proportion of the consumer's biomass that was derived from each organic matter source; the percent frequency ( $y$-axis) is the percent of possible source combinations that resulted in that particular source proportion. Each panel is the average of four
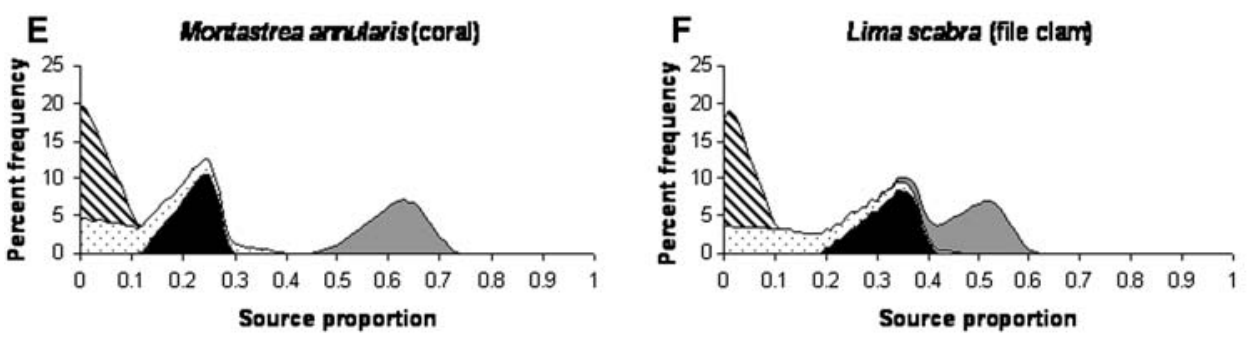
individuals sampled in the same habitat type at a site. The consumers in $\mathbf{A}-\mathbf{E}$ were sampled at Zapatillas Caye, F-G were sampled on the Reef Slope at Red Point, and h was sampled on the Reef Slope at Gallinazo.
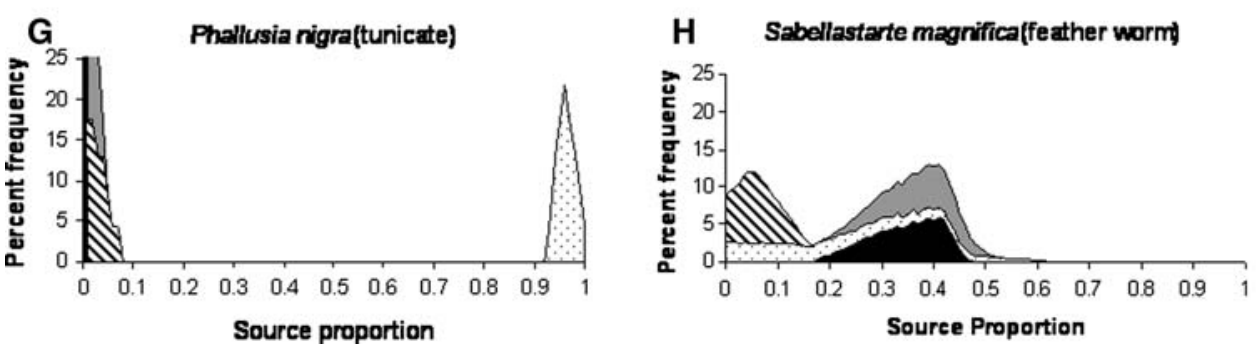

2002), this became a significant source for $N$. erecta with a contribution ranging from 62 to $100 \%$ along the intact transects and from 72 to $100 \%$ along the cleared transects.

\section{Discussion}

Contrary to recent assumptions (for example, Newell and others 1995; Jennerjahn and Ittekkot 2002), several sessile filter feeding and predatory reef-forming invertebrates on Caribbean reefs off Bocas del Toro, Panama, incorporated from less than a quarter to half of their organic matter from mangroves as determined by $\delta^{34} \mathrm{~S}$ and $\delta^{13} \mathrm{C}$ concentration-dependent isotopic mixing models, assuming all relevant OM sources were included. Mangrove-derived nutrient incorporation varied among species and sites with corals demonstrating the greatest variability among species and locations, probably due to their chimeric nature of functioning as both autotrophs and heterotrophs (Porter 1976). The species variability might reflect differences in feeding habitat or carbon source proportions. Site-to-site variability may be related to hydrography affecting delivery rates of mangrovederived particulate and dissolved OM due to currents. Our results demonstrate mangrove-derived nutrient incorporation in organisms located close to mangroves (for example, within $0.5 \mathrm{~km}$ at the $\mathrm{Al}-$ mirante Bay sites) as well as in organisms far from mangroves (for example, on reefs more than $10 \mathrm{~km}$ away at Zapatillas Caye). There were no differences in mangrove contribution based on mangrove condition (intact versus cleared) possibly due to the relatively small size of cleared areas $(<300 \mathrm{~m})$ and the close proximity to intact mangroves. This was 

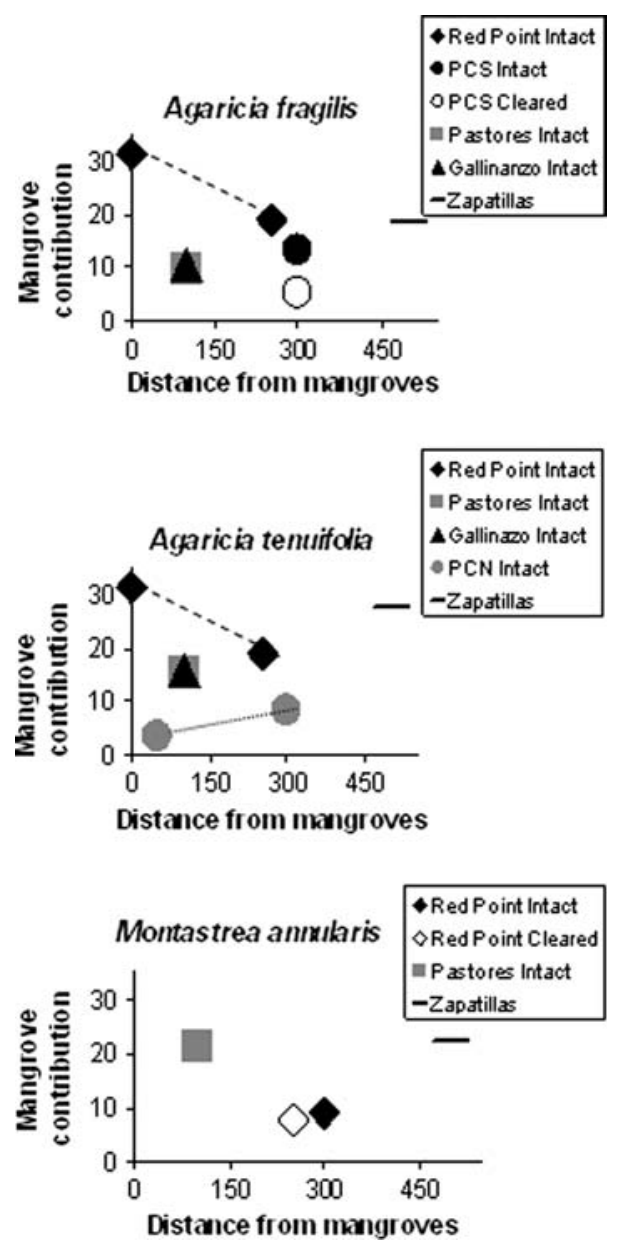

Figure 4. The change in percent mangrove-derived nutrient contribution for three coral species with distance from a mangrove source and across sites. Open symbols represent cleared areas and solid symbols represent intact areas. Symbol shape denotes site where species was present. Lines connect transects within a site. Standard error bars are smaller than the symbols.

evidenced by the extensive overlap of ranges of potential mangrove contributions for intact versus cleared areas across individual sites and species for various taxa: $0-54 \%$ vs. $0-57 \%$ for sponges, $10-41 \%$ vs. $7-39 \%$ for file clams, $18-47 \%$ vs. $38-52 \%$ for feather dusters, and $0-44 \%$ vs. $0-30 \%$ for corals.

Multiple potential pathways of mangrove-derived nutrient delivery could explain the availability of these nutrients to corals and reef-dwelling filter feeders on reefs at various distances from mangroves. First, previous research has demonstrated that reef fishes visiting mangroves incorporate mangrove-derived nutrients to varying degrees (Deegan 1993; Sheaves and Molony 2000; Cocheret de la Moriniere and others 2003;
Nagelkerken and van der Velde 2004a, b). These fish may carry mangrove-derived nutrients back to the reef in their gut and deposit them via solid waste, similar to the finding by Meyer and others (1983) that the reef fish Haemulon spp. (grunts) carries seagrass-derived nutrients to reefs via solid waste deposition thereby contributing to the nutrients available to coral heads around which the grunts reside.

Mangrove-derived nutrients may also reach sessile reef invertebrates via outwelling of particulate and dissolved OM from mangrove systems to reefs (Lee 1995). The high primary productivity and rapid turnover of OM within mangrove forests allows for large quantities of dissolved and particulate materials to be exported to adjacent coastal waters (Odum and Heald 1972; Twilley 1985). Jennerjahn and Ittekkot $(1997,2002)$ argue that although mangrove leaf litter fall and water exchange within coastal areas is high, leading to significant carbon export to coastal zone areas, mangrove-derived OM is only a minor contribution to higher organisms due to lower nutrient content. In contrast, our findings reveal mangrove-derived nutrient contributions averaging (across all species and sites sampled) $26 \%$ of the nutrients and energy to sessile reef invertebrates as far as $10 \mathrm{~km}$ from a mangrove source. Possibly, the high rate of transfer offsets the low nutrient concentration such that small supplies of allochthonous materials may have a big impact on adjacent systems. The lack of a mangrove signal in our grab samples of phytoplankton may indicate that mangrove particulate matter is exported in pulses associated with certain tides or storm events.

Within a site, filter feeding taxa varied greatly in their uptake of the various nutrient sources. This variability may be due to different feeding modes and levels of selectivity among taxa, including varying capacities to filter different particle sizes. For example, previous research indicates that ascidians may feed selectively and show seasonal shifts in food preference (Yahel 2003). Similarly, preliminary evidence indicates that some sponges feed selectively, regardless of particle size (Yahel and Eerkes-Medrano, pers. comm.). Our results indicate that the tunicate $P$. nigra is primarily taking in phytoplankton, incorporating little to no OM from mangroves, seagrass or macroalgae (Figure 3; Supplementary Table 1). On the other hand, rough file clams, magnificent feather duster worms, and two of the three sponge species incorporate significant amounts of mangrove- and seagrass-derived nutrients whereas micro- and macroalgae uptake are so variable that the importance of these sources is inconclusive. 


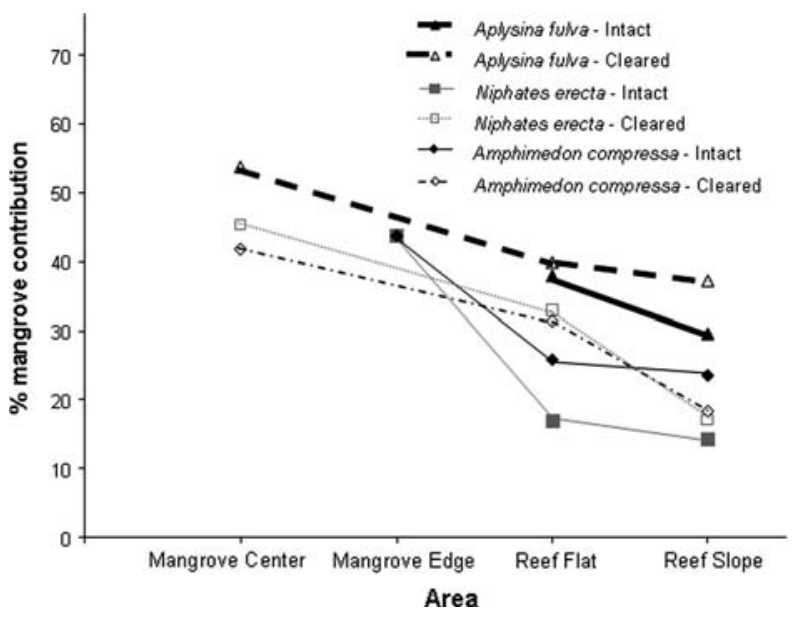

Figure 5. The percent contribution from mangroves to three sponge species versus distance from cleared and intact mangrove habitat. (For Niphates erecta, the mangrove edge and mangrove center samples were based on concentration-dependent mixing model analyses including an additional source, mangrove wood [Fry and Smith 2002]). Standard error bars are smaller than the symbols.

Molluscan and annelid filter feeders, which are typically more generalist feeders, reflect the highest and most consistent contribution from mangroves, each with constrained ranges within a site. The rough file clam (L. scabra) is found predominantly on the reef slope with a moderate $(7-41 \%)$ contribution from mangroves. The magnificent feather duster worm, S. magnifica, reflects a consistently high contribution from mangroves (18-52\%) both in its tissue and tube composition. Moreover, individuals growing closer to mangroves (on the Reef Flat) demonstrated a more conclusive mangrove contribution relative to those on the Reef Slope (Supplementary Table 1).

The three sponges sampled varied in their uptake of mangrove-derived nutrients. A. compressa, the erect rope sponge found predominantly on deeper reefs, reflects intermediate levels of mangrovederived nutrient incorporation $(6-47 \%)$, with variable incorporation of phytoplankton-, macroalgal, and seagrass-derived nutrients. $N$. erecta, the lavender rope sponge, commonly found growing on mangrove prop roots as well as in deeper reef habitat, reflects variable incorporation from mangrove detrital leaves $(0-52 \%)$ with highly variable incorporation of phytoplankton, seagrass, and macroalgal based sources (Figure 3). Previous research (Ellison and others 1996) indicates that sponge attachment to mangrove prop roots enhances growth rates of some species possibly via nutrient exchange; because $N$. erecta occurs naturally on mangrove prop roots, this species may be adapted to utilize mangrove-derived nutrients directly from the woody roots (mangrove wood) as well as from particulate or dissolved OM from detrital leaf or woody matter. A. fulva, the scattered pore rope sponge found on shallow inshore reefs, reflected a higher (14-57\%) contribution from mangrove-derived nutrients, and an intermediate to high contribution from seagrass $(2-50 \%)$, and variable contributions from microalgae and macroalgae.

Coral species range from primarily autotrophic to heavily heterotrophic depending on species and ecological variables (Porter 1976), and this variation in function is expected to affect their isotope ratios. Reflecting the variability in feeding ecology and habitat, the mangrove contribution to coral tissue was variable among species (Figure 3), depth, and water exchange (Supplementary Table 2 ). Of the taxa sampled, coral species showed a greater variability and generally lower level of mangrove nutrient incorporation rates both within and among species. The complexity of trophic position and the physiological plasticity (variability of heterotrophy) of some coral species (Grottoli and others 2006) may contribute to this variability because a coral signature is a composite of the animal tissue and the endosymbiotic dinoflagellate within the coral cells. Corals' ability to function autotrophically and heterotrophically has important consequences for the carbon source and isotopic ratio. Within a coral species, the mangrove contribution was also variable among sites possibly based on distance from mangrove source as well as differences in light availability and depth, which can affect heterotrophy (Muscatine and others 1989; Heikoop and others 1998). Montastrea annularis, a large-polyped, predominantly heterotrophic species, showed significant variability in mangrovederived nutrient incorporation among sites (Supplementary Table 2). Of note, at Zapatillas Caye, an open ocean site with high wave energy and presumably lower concentrations of phytoplankton, incorporation of mangrove-derived nutrients was high. Current flow into Almirante Bay is predominantly through Bocas del Drago (to the North, Figure 1; E.G. pers. obs.) and out through the southern openings among the islands. Therefore, the pattern of varying mangrove nutrient incorporation across sites observed for $M$. annularis may reflect differing nutrient availability due to currents.

Results of the sponge transplant experiment indicate that the three species may be incorporating 
nutrients based on availability. For the three sponge species, transplants into the mangrove center and edge habitats incorporated the most mangrove-derived nutrients and the contribution declined with distance from the mangroves as follows: $\mathrm{MC}>\mathrm{ME}>\mathrm{RF}>\mathrm{RS}$ transects (Figure 5). This finding is consistent with results from the naturally occurring sponge samples and indicates that sponge selectivity in uptake of OM may be correlated with availability and raises the possibility that loss of mangroves and therefore mangrovederived primary production may lead to shifts in nutrient sources.

This study demonstrates incorporation of mangrove nutrients across multiple taxa of reef-building sessile invertebrates on Caribbean coral reefs. The question remains whether mangrove-derived nutrients provide essential nutrients or minerals that would be limiting if mangrove nutrients were to become unavailable. Incorporation of mangrovederived nutrients, as shown by stable isotopes, does not demonstrate limitation, only uptake. This research therefore highlights some key areas for further research. For example, do sessile reef invertebrates that have incorporated mangrovederived nutrients exhibit higher growth rates or reproductive output? Does the nutritional value of mangrove-derived nutrients vary among consumers? Understanding the importance of mangroves as a nutrient source for sessile reef invertebrates and what shifts in uptake would follow from a loss of mangrove production may be relevant to understanding changes in coral reef communities as both mangrove forests and coral reefs respond to increased threats on a global scale.

In this paper, we have presented evidence suggesting that Odum and Heald (1972, 1975) were correct in their assertion that mangrove nutrients contribute to food webs both within mangroves and in adjacent systems as far away as $10 \mathrm{~km}$. Despite their low $\mathrm{OM}$ and nutritional quality (France 1998; Alongi 1990), mangroves may thus be important sources of essential nutrients on reefs and their decline as a consequence of coastal development may lead to a reduction of OM for sessile reef organisms. If mangrove-derived nutrients are, indeed an important source of essential nutrients or a necessary nutrient source on reefs with low levels of phytoplankton, loss of mangrove habitat may lead to a reduction in OM for certain sessile reef organisms. How this loss of mangrove-derived nutrients will affect food availability in a changing ocean and on increasingly stressed coral reefs is a critical area for future research.

\section{ACKNOWLEDGMENTS}

We thank C. Diaz, B. Fry, B. Griffis, R. Brooks, S. Silva, R. Doucett, C. Kendall, S. Perez, V. Weis, and B. Hungate for their ideas, suggestions, interpretations, and assistance with the sample processing. We also thank K. Purcell, K. Frasier, N. Ehlers, A. Amat, and M. Brown for their assistance in the lab and field. This manuscript was significantly improved through discussions and input from V. Weis, B. Menge, J. Lubchenco, J. Benstead, and two anonymous reviewers. Funding for this study was provided by a Fulbright Fellowship, an NSF-GRF, an Oregon State University Aquaculture Collaborative Research Support Program Fellowship, The David and Lucile Packard Foundation, a Smithsonian Tropical Research Institution-Supplemental Research Award, an Anchor Environmental Scholarship, OSU URISC and IURP Fellowships, a Department of Zoology Research Fellowship from Oregon State University, and in-kind support from the USGS Menlo Park Laboratory and the US EPA National Health and Environmental Effects Laboratory, Western Ecology Division. This manuscript has been subjected to US EPA's peer and administrative review, and it has been approved for publication as an EPA document. Mention of trade names or commercial products does not constitute endorsement or recommendation for use.

\section{REFERENCES}

Alongi DM. 1990. Effects of mangrove detrital outwelling on nutrient regeneration and oxygen fluxes in coastal sediments of the central Great Barrier Reef lagoon. Estuar Coast Shelf Sci 31:581-98.

Ambler JW, Alcala-Herrera J, Burke R. 1994. Trophic roles of particle feeders and detritus in a mangrove island prop root ecosystem. Hydrobiologia 292-293:437-46.

Benstead JP, March JG, Fry B, Ewel KC, Pringle CM. 2006. Testing IsoSource: stable isotope analysis of a tropical fishery with diverse organic matter sources. Ecology 87:326-33.

Bouillon S, Borges AV, Castaneda-Moya E, Diele K, Dittmar T, Duke NC, Kristensen E, Lee SY, Marchand C, Middelburg JJ, Rivera-Monroy VH, Smith TJ III, Twilley RR. 2008. Mangrove production and carbon sinks: a revision of global budget estimates. Global Biogeochem Cycles 22 (GB2013).

Bouillon S, Koedam N, Raman AV, Dehairs F. 2002. Primary producers sustaining macroinvertebrate communities in intertidal mangrove forests. Oecologia 130:441-8.

Bouillon S, Mohan PC, Sreenivas N, Dehairs F. 2000. Sources of suspended organic matter and selective feeding by zooplankton in an estuarine mangrove ecosystem as traced by stable isotopes. Mar Ecol Prog Ser 208:79-92.

Cocheret de la Moriniere EC, Pollux BJA, Nagelkerken I, Hemminga MA, Huiskes AHL, van der Velde G. 2003. Ontogenetic dietary changes of coral reef fishes in the mangrove-seagrassreef continuum: stable isotopes and gut-content analysis. Mar Ecol Prog Ser 246:279-89. 
Connell JH, Hughes TP, Wallace CC. 1997. A 30-year study of coral abundance, recruitment, and disturbance at several scales in space and time. Ecol Monogr 67:461-88.

Deegan LA. 1993. Nutrient and energy transport between estuaries and coastal marine ecosystems by fish migration. Can J Fish Aquat Sci 50:74-9.

Duarte CM, Cebrian J. 1996. The fate of marine autotrophic production. Limnol Oceanogr 41:1758-66.

Ellison AM, Farnsworth EJ, Twilley RR. 1996. Facultative mutualism between red mangroves and root-fouling sponges in Belizean mangal. Ecology 77:2431-44.

France R. 1998. Estimating the assimilation of mangrove detritus by fiddler crabs in Laguna Joyuda, Puerto Rico, using dual stable isotopes. J Trop Ecol 14:413-25.

France RL, Peters RH. 1997. Ecosystem differences in the trophic enrichment of 13C in aquatic food webs. Can J Fish Aquat Sci $54: 1255-8$.

Fry B, Smith TJ III. 2002. Stable isotope studies of red mangroves and filter feeders from the Shark River estuary, Florida. Can J Fish Aquat Sci 70:871-890.

Grottoli AG, Rodrigues LJ, Palardy JE. 2006. Heterotrophic plasticity and resilience in bleached corals. Nature 440:1 186-9.

Heikoop JM, Dunn JJ, Risk MJ. 1998. Relationship between light and the d15N of coral tissue: examples from Jamaica and Zanzibar. Limnol Oceanogr 43:909-20.

Jennerjahn TC, Ittekkot V. 1997. Organic matter in sediments in the mangrove areas and adjacent continental margins of Brazil. Oceanol Acta 20:359-69.

Jennerjahn TC, Ittekkot V. 2002. Relevance of mangroves for the production and deposition of organic matter along tropical continental margins. Naturwissenschaften 89:23-30.

Lee SY. 1995. Mangrove outwelling: a review. Hydrobiologia 295:203-12

Loneragan NR, Bunn SE, Kellaway DM. 1997. Are mangroves and seagrasses sources of organic carbon for penaeid prawns in a tropical Australian estuary? A multiple stable-isotope study. Mar Biol 130:289-300.

McCutchan JH, Lewis WM, Kendall C, McGrath CC. 2003. Variation in trophic shift for stable isotope ratios of carbon, nitrogen, and sulfur. Oikos 102:378

Meyer JL, Schultz ET, Helfman GS. 1983. Fish schools: an asset to corals. Science 220:1047-9.

Muscatine L, Porter JW, Kaplan IR. 1989. Resource partitioning by reef corals as determined from stable isotope composition. Mar Biol 100:185-93.

Nagelkerken I, van der Velde G. 2004a. Are Caribbean mangroves important feeding grounds for juvenile reef fish from adjacent seagrass beds? Mar Ecol Prog Ser 274:143-51.
Nagelkerken I, van der Velde G. 2004b. Relative importance of interlinked mangroves and seagrass beds as feeding habitats for juvenile reef fish on a Caribbean island. Mar Ecol Prog Ser 274:153-9.

Newell RIE, Marshall N, Sasekumar A, Chong VC. 1995. Relative importance of benthic microalgae, phytoplankton, and mangroves as sources of nutrition for penaeid prawns and other coastal invertebrates from Malaysia. Mar Biol 123:595-606.

Odum WE, Heald EJ. 1972. Trophic analyses of an estuarine mangrove community. Bull Mar Sci 22:671-738.

Odum WE, Heald EJ. 1975. The detritus-based food web of an estuarine mangrove community. In: Cronin LE, Ed. Estuarine research. New York: Academic Press. p 265-86.

Porter JW. 1976. Autotrophy, hterotrphy and resource partitioning in Caribbean reef-building corals. Am Nat 110:731-42.

Phillips DL, Gregg JW. 2003. Source partitioning using stable isotopes: coping with too many sources. Oecologia 136:261-9.

Phillips DL, Koch PL. 2002. Incorporating concentration dependence in stable isotope mixing models. Oecologia 130:114-25.

Suchanek TH, Carpenter RC, Whitman JD, Harvell CD. 1983. Sponges as important space competitors in deep Caribbean coral reef communities. In: Reaka ML, Ed. The ecology of deep and shallow coral reefs. Symposia series for undersea research. Rockville, MD: NOAA Undersea Research Program. p 55-60.

Sheaves M, Molony B. 2000. Short-circuit in the mangrove food chain. Mar Ecol Prog Ser 199:97-109.

Twilley RT. 1985. The exchange of organic carbon in basin mangrove forests in a southwest Florida estuary. Estuar Coast Shelf Sci 20:543-57.

Vander Zanden MJ, Rasmussen JB. 2001. Variation in d15N and d13C trophic fractionation: implications for aquatic food web studies. Limnol Oceanogr 46:2061-6.

Weis VM, Reynolds WS, deBoer MD, Krupp DA. 2001. Hostsymbiont specificity during onset of symbiosis between the dinoflagellates Symbiodinium spp. and planula larvae of the scleractinian coral Fungia scutaria. Coral Reefs 20:301-8.

Werry J, Lee SY. 2005. Grapsid crabs mediate link between mangrove litter production and estuarine planktonic food chains. Mar Ecol Prog Ser 293:165-76.

Wulff JL. 1997. Mutualisms among species of coral reef sponges. Ecology 78:146-59.

Wulff JL. 2000. Functional roles of sponges on coral reefs. Washington, DC: USAID.

Yahel G. 2003. Feeding on ultraplankton and dissolved organic carbon in coral reefs: from the individual grazer to the community. PhD Dissertation. Hebrew University, Jerusalem, Israel. 